\title{
COMPARATIVE ANALYSIS OF FINANCIAL PERFORMANCE PT KALBE FARMA, Tbk. AND PT KIMIA FARMA (Persero) Tbk USING DU PONT SYSTEM IN 2012-2014
}

\author{
Nenden Kostini*, R Ratna Meisa Dai*, Dinda Rizki Oktaviani** \\ *Department of Business Administration Science \\ **Graduate Business Administration Science \\ Faculty of Social and Political Science, Padjadjaran University \\ Email:kostini@yahoo.co.id,Lexsa_dai@yahoo.com,dindarizkio@yahoo.co.id
}

\begin{abstract}
This study aimed to compare the financial performance of PT Kalbe Farma Tbk and PT Kimia Farma (Persero) Tbk using du Pont system in 2012 until 2014. The company's financial performance seen from a return on investment along with its constituent components consisting of total assets turnover and net profit margin. The method used in this study is a comparative quantitative approach using data from the financial statements of PT Kalbe Farma Tbk and PT Kimia Farma (Persero) Tbk years 2012-2014 which includes the balance sheet and profit and loss. The processed data is secondary data. Data were analyzed using analysis du pont system. The results showed that the financial performance of PT Kalbe Farma Tbk and PT Kimia Farma (Persero) Tbk in 2010 and 2012 continued to decline. Return on investment of PT Kalbe Farma Tbk above - average industry return on investment while PT Kimia Farma Tbk is below average average industry. PT Kalbe Farma Tbk have better financial performance of PT Kimia Farma (Persero) Tbk.
\end{abstract}

Keywords: Financial performance, return on investment (ROI), total asset turnover, net profit margin, du pont system

\section{ANALISIS PERBANDINGAN KINERJA KEUANGAN PT KALBE FARMA TBK DAN PT KIMIA FARMA PERSERO (TBK) DENGAN MENGGUNAKAN METODE DU PONT SISTEM TAHUN 2012 - 2014}

\begin{abstract}
ABSTRAK
Penelitian ini bertujuan untuk mengetahui perbandingan kinerja keuangan PT Kalbe Farma Tbk dan PT Kimia Farma (Persero) Tbk dengan menggunakan du pont system tahun 2012 hingga 2014. Kinerja keuangan perusahaan dilihat dari return on investment beserta komponen penyusunnya yang terdiri dari total assets turnover dan net profit margin.

Metode yang digunakan dalam penelitian ini adalah komparatif dengan pendekatan kuantitatif dengan menggunakan data laporan keuangan PT Kalbe Farma Tbk dan PT Kimia Farma (Persero) Tbk tahun 2012 - 2014 yang meliputi laporan neraca dan laba rugi. Data yang diolah merupakan data skunder. Teknik analisis data menggunakan analisis du pont system.

Hasil penelitian menunjukan bahwa kinerja keuangan PT Kalbe Farma Tbk dan PT Kimia Farma (Persero) Tbk tahun 2010 hingga 2012 terus mengalami penurunan. Return on investment PT Kalbe Farma Tbk diatas rata - rata industri sedangkan return on investment PT Kimia Farma Tbk berada dibawah rata - rata industri. PT Kalbe Farma Tbk memiliki kinerja keuangan yang lebih baik dari pada PT Kimia Farma (Persero) Tbk.

Kata kunci: Kinerja keuangan, return on investment (ROI), total asset turnover, net profit margin, du pont system
\end{abstract}




\section{PENDAHULUAN}

Perkembangan industri farmasi di Indonesia saat ini semakin maju, hal ini terbukti dengan meningkatnya pasar farmasi di Indonesia. Seperti yang di lansir pada www.jpnn.com menyatakan bahwa industri farmasi masih dapat bertahan ditengah perekonomian negara yang sedang lesu. Pada semester I 2015 industri farmasi Indonesia tumbuh $10-15 \%$. Pada tahun 2014, industri farmasi Indonesia mencatatkan omzet sebesar Rp 50 triliun dan tahun 2015 menargetkan pendapatan $\mathrm{Rp} 65$ triliun atau tumbuh sekitar 15 persen. Salah satu faktor yang menyebabkan industri farmasi Indonesia dapat tumbuh karena adanya JKN (Jaminan Kesehatan Nasional) dan BPJS (Badan Penyelenggara Jaminan Sosial) kesehatan. JKN dan BPJS kesehatan menyerap pasar obat karena jumlah orang yang berobat menjadi semakin banyak dan dapat membuat market share obat - obatan semakin meluas.

PT Kalbe Farma Tbk dan PT Kimia Farma (Persero) Tbk merupakan perusahaan farmasi yang bergerak dibidang kesehatan, obat obatan serta teknologi yang berhubungan dengan kesehatan dan obat - obatan bagi masyarakat. PT Kalbe Farma Tbk dan PT Kimia Farma (Persero) Tbk sudah go public dan terdaftar dalam Bursa Efek Indonesia. PT Kalbe Farma Tbk dan PT Kimia Farma (Persero) Tbk merupakan perusahaan sejenis yang memproduksi farmasi, suplemen dan nutrisi. PT Kalbe Farma Tbk merupakan market leader pada sektor farmasi dan PT Kimia Farma (Persero) Tbk merupakan perusahaan farmasi BUMN terbesar di Indonesia yang sudah go public.

Tingginya pertumbuhan pasar industri farmasi Indonesia dan luasnya market share obat - obatan meningkatkan persaingan dalam industri farmasi sehingga keberlangsungan suatu perusahaan tidak lepas dari faktor kualitas obat dan manajemen dalam menjalankan kegiatan produksi dan operasi karena produk dan manajemen yang berkualitas mencerminkan keberhasilan setiap perusahaan.

Cara mengevaluasi kondisi keuangan dan kinerja keuangan perusahaan, harus dibutuhkan tolok ukur tertentu. Tolak ukur yang sering digunakan adalah rasio, indeks dan data perbandingan. Kinerja keuangan dapat dilihat pada laporan keuangan yang dimiliki oleh perusahaan yang bersangkutan dan terlihat dari informasi yang diperoleh dari neraca (balancesheet), laporan laba rugi (income statement), dan laporan arus kas (cashflow) (Dwi Lestari, Wuryaningsih \& Dziqron, 2014). Analisis Du Pont System adalah analisis yang digunakan untuk melihat prestasi kinerja perusahaan (Suwita, 2013). Hasil pengembalian atas total aktiva dan mengukur efektivitas perusahaan dalam memanfaatkan sumber daya yang disebut dengan hasil pengembalian investasi. Berdasarkan data - data yang telah didapat penulis ingin mengetahui kinerja keuangan manakah yang lebih baik antara kinerja keuangan PT Kalbe Farma Tbk dan PT Kimia Farma Tbk tahun 2012 - 2014 yang dianalisis dengan metode Du Pont System, maka peneliti mengambil topik penilaian kinerja keuangan yang berjudul "Analisis Perbandingan Kinerja Keuangan PT Kalbe Farma Tbk dan PT Kimia Farma (Persero) Tbk dengan Menggunakan Du Pont System Tahun 2012 - 2014".

\section{Identifikasi Masalah}

Berdasarkan uraian latar belakang di atas, penulis mengidentifikasi masalah yaitu:

a. Bagaimana kinerja keuangan PT Kalbe Farma Tbk tahun 2012 - 2014 dengan menggunakan analisis Du Pont System.

b. Bagaimana kinerja keuangan PT Kimia Farma Tbk tahun 2012 - 2014 dengan menggunakan analisis Du Pont System.

c. Kinerja keuangan manakah yang lebih baik antara kinerja keuangan PT Kalbe Farma Tbk dan PT Kimia Farma Tbk tahun 2012 - 2014 yang dianalisis dengan $\mathrm{Du}$ Pont System. 
e. Solusi

\section{TINJAUAN PUSTAKA}

\section{Kinerja Keuangan}

Penilaian kinerja suatu perusahaan dapat dijadikan acuan untuk melihat apakah suatu perusahaan telah menjalankan suatu manajemen yang baik. Penilaian sebuah kinerja perusahaan salah satunya dapat dilakukan dengan melihat sisi kinerja keuangan (financial performance). Kinerja keuangan perusahaan yang baik merupakan hal penting yang harus dicapai oleh setiap perusahaan karena kinerja tersebut merupakan cerminan dari kemampuan perusahaan dalam mengelola dan mengalokasikan sumber dayanya (Harapan, 2015).

Menurut Van Horne dan Wachowicz (2008:135), "To evaluate the financial condition and performance of a firm, the financial analyst needs certain yardstick. The yardstick frecuently used is a ratio, index, relating two pieces of financial data of two each other". Artinya, untuk mengevaluasi kondisi keuangan dan kinerja keuangan perusahaan, harus dibutuhkan tolok ukur tertentu. Tolak ukur yang sering digunakan adalah rasio, indeks, dan data perbandingan. Kinerja keuangan dapat dilihat pada laporan keuangan yang dimiliki oleh perusahaan yang bersangkutan dan terlihat dari informasi yang diperoleh dari neraca (balancesheet), laporan laba rugi (income statement), dan laporan arus kas (cashflow). Menurut Munawir (2014:31), ada beberapa tujuan dari pengukuran kinerja keuangan untuk mengetahui tingkat likuiditas, solvabilitas, profitabilitas dan stabilitas usaha. Menurut Jumingan (2011:239) lima tahap proses analisis kinerja keuangan secara terperinci dijelaskan sebagai berikut:
a. Review data laporan
b. Menghitung dengan menggunakan berbagai metode dan teknik analisis
c. Membandingkan atau mengukur
d. Menginterpretasi

\section{Rasio Keuangan}

Menurut Van Horne dan Machowicz (2008:135) menjelaskan bahwa:

"Financial ratio to evaluate a firm's financial condition and performance, the financial analysis need to perform checkup on various aspects of a firm's financial healts. A tool frequently used during these checkups is a financial ratio, or indext, which relates two piece of financial data by dividing one quantity by the other."

Artinya, rasio keuangan untuk mengevaluasi kondisi dan kinerja keuangan perusahaan, analisis keuangan perlu memeriksa berbagai aspek kesehatan keuangan perusahaan dengan sebuah alat yang sering digunakan yaitu berupa rasio, atau indeks, yang berhubungan dengan dua bagian dari data keuangan yaitu yang berasal dari neraca dan laporan laba rugi.

\section{Total Asset Turnover}

Menurut Van Horne dan Wachowicz (2008:142), "Activity ratio measure how effectivity the firm is using its assets. Artinya, rasio aktivitas mengukur seberapa efektif perusahaan menggunakan asetnya untuk melakukan berbagai aktivitas dalam menjalankan operasinya baik dalam kegiatan penjualan, pembelian dan kegiatan lainnya..

Menurut Van Horne dan Wachowicz (2008:148), "Total Asset Turnover is the relationship of net sales to total assets." Artinya, perputaran aset merupakan ukuran efektivitas pemanfaatan aktiva dalam menghasilkan penjualan. Semakin besar perputaran aset semakin baik kinerja keuangan perusahaan dalam mengelola asetnya. Komponen - komponen dari total aset yaitu aset lancar dan aset tetap. Aset lancar meliputi kas, piutang dan persediaan. Aset tetap meliputi tanah, bangunan, sarana dan prasarana, kendaraan. Komponen total aset perusahaan 
dapat dilihat dari neraca pada laporan keuangan perusahaan. Total Assets Turnover dapat dihitung dengan rumus:

$$
\text { Total asset turnover }=\frac{\text { Penjualan }}{\text { Total aktiva }}
$$

\section{Net Profit Margin dan Return On Investment}

Net Profit Margin dan Return On Investment merupakan bagian dari rasio profitabilitas. Menurut Ross et al (2002:64), "Profitability ratio measures how efficiently a company has used assets and manage operations in the form of net income." Artinya, rasio profitabilitas digunakan untuk mengukur seberapa efisien suatu perusahaan telah menggunakan aset dan mengelola operasinya berupa laba bersih.

Menurut Van Horne dan Wachowicz (2008:150), "Net profit margin is a measure of the company's sales gains after calculating all the costs and income taxes. This ratio measures the company's net income on the sale." Artinya, net profit margin merupakan ukuran keuntungan penjualan perusahaan setelah menghitung seluruh biaya dan pajak penghasilan. Rasio ini menujukkan penghasilan bersih perusahaan atas penjualan. Net profit margin merupakan indikator seberapa besar laba bersih dari setiap rupiah pendapatan. Net profit margin yang tinggi tidak hanya sekedar menunjukan kekuatan bisnis tetapi juga semangat yang kuat pihak manajemen untuk melakukan kontrol terhadap biaya. Perusahaan yang memiliki efisiensi tinggi menunjukan kemampuan perusahaan untuk menghasilkan laba yang tinggi dari penjualannya.

Net profit margin dihitung dengan rumus

$$
=\frac{\text { Laba bersih setelah pajak }}{\text { Penjualan bersih }}
$$

Menurut Van Horne dan Marchowicz (2008:150), "Return on investment measures the overall effectiveness in generating income through available assets,

Power to generate profit from the capital invested". Artinya, return on investment mengukur efektivitas dalam menghasilkan laba melalui aset yang tersedia atau kemampuan untuk menghasilkan laba dari modal yang diinvestasikan, modal tersebut berupa aset perusahaan. Nilai return on investment yang tinggi menunjukan kinerja keuangan perusahaan yang tinggi karena tingkat pengembalian investasinya besar.

\section{Analisis Perbandingan}

Ada banyak cara untuk menilai kinerja keuangan perusahaan, salah satunya dengan cara analisis perbandingan. Van Horne dan Machowicz (2008:136), "The comparison of financial ratios is

1. Internal Comparisons; The analysis of financial ratios involves two types of comparison. First, the analyst can compare a present ratio with past and expected future ratios for the same company

2. External Comparisons and Sources of Industry Ratios; The second method of comparison involves comparing the ratios of one firm with those of similar firms or with industry averages at the same point in time."

Artinya Van Horne dan Machowicz menjelaskan bahwa ada dua cara untuk melakukan perbandingan rasio keuangan. Pertama dapat dilakukan dengan cara perbandingan internal yaitu analisis rasio keuangan melibatkan dua jenis pembanding, rasio saat ini dengan rasio masa lalu dan masa depan untuk perusahaan yang sama dan cara kedua dengan perbandingan eksternal yaitu perbandingan dengan perusahaan lain dan sumber rasio industri dengan membandingkan dengan rata-rata industri pada titik yang sama dalam waktu. Kondisi kesehatan keuangan perusahaan dapat dikatakan sehat jika berada di atas rata - rata industri dan kondisi kesehatan keuangan perusahaan dikatakan tidak sehat jika kinerja keuangan perusahaan berada dibawah rata - rata industri sejenis. 


\section{Du Pont System}

Van horne dan Wachowicz (2005:150) menjelaskan bahwa in about $1919 \mathrm{Du}$ Pont Company began to use a particular approach to ratio analysis to evaluate the firm's effectivitness. One variation of this Du Pont approach has special relavance to understanding a firm's Return on investment (ROI). Artinya Van Horne dan Wachowicz (2005) menjelaskan bahwa sekitar tahun 1919, Du Pont Company menggunakan pendekatan khusus untuk menganalisis rasio agar dapat mengevaluasi efektivitas perusahaan. Salah satu variasi dari pendekatan $D u$ Pont system memiliki relevansi khusus untuk memahami pengembalian atas investasi perusahaan. Sistem $\mathrm{Du}$ pont sering digunakan untuk pengendalian divisi, prosesnya disebut dengan pengendalian terhadap tingkat pengembalian investasi. Jika ROI untuk divisi tertentu berada di bawah angka yang ditargetkan, melalui sistem $\mathrm{Du}$ pont dapat ditelusuri sebab-sebab terjadinya penurunan ROI." Persamaan Du Pont (Gitman, 2009), yaitu :

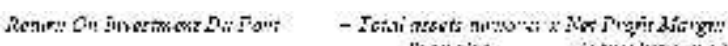

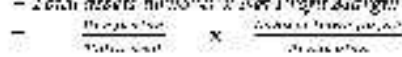

Menurut Munawir (2014:91) terdapat beberapa kegunaan return on investment dengan metode Du Pont System yaitu :

a. Menyeluruh dan Komprehensif

b. Perbandingan dengan perusahaan sejenis

c. Mengukur efisiensi

d. Mengukur profitabilitas

e. Sebagai kontrol dan perencanaan

\section{Kerangka Pemikiran}

Kinerja keuangan dapat dilihat pada laporan keuangan yang dimiliki oleh suatu perusahaan. Dengan melakukan analisa lebih mendalam terhadap laporan keuangan perusahaan maka dapat diperoleh informasi yang bermanfaat mengenai hal-hal yang berkaitan dengan kinerja perusahan. Analisis laporan keuangan dapat menggali dan mengungkapkan berbagai hal yang tersembunyi dari dalam laporan keuangan biasa. Menurut Warsono (2003:24) cara untuk memperoleh informasi dari laporan keuangan adalah dengan melakukan analisis rasio, analisis nilai tambah pasar atau market value added (MVA), analisis nilai tambah ekonomis atau economic value added (EVA), Balance Score Card, analisis CAMEL dan Du Pont System.

Dari sekian banyak analisis yang digunakan maka $\mathrm{Du}$ Pont System dapat dijadikan sebagai salah satu pilihan. Analisis Du Pont System adalah analisis yang digunakan untuk mengetahui kinerja perusahaan berupa kemampuan perusahaan dalam memanfaatkan sumber daya yang dimiliki untuk menghasilkan keuntungan. Hasil akhir dari analisis Du Pont System dikenal dengan nama return on investment atau hasil pengembalian investasi. Analisis Du Pont System ini menguraikan pos-pos terkecil untuk mengetahui seberapa besar tingkat pengembalian investasi. Jika return on investment berada dibawah angka yang ditargetkan, melalui $\mathrm{Du}$ Pont System dapat ditelusuri sebab-sebab terjadinya penurunan return on investment. Return on investment dalam analisis Du Pont System dihasilkan dari perkalian antara total assets turnover dan net profit margin. Total assets turnover dihasilkan dari penjualan dibagi total aset dapat kita lihat dalam laporan neraca dan laba rugi perusahaan. Total aset dihasilkan dari penjumlahan aset lancar dan aset tetap. Sedangkan net profit margin dihasilkan dari laba bersih dibagi penjualan yang dapat kita lihat dalam laporan laba rugi perusahaan. Laba bersih perusahaan dihasilkan dari pendapatan dikurang total biaya, termasuk biaya bunga dan pajak.

Untuk lebih jelasnya dapat dilihat pada gambar berikut ini: 


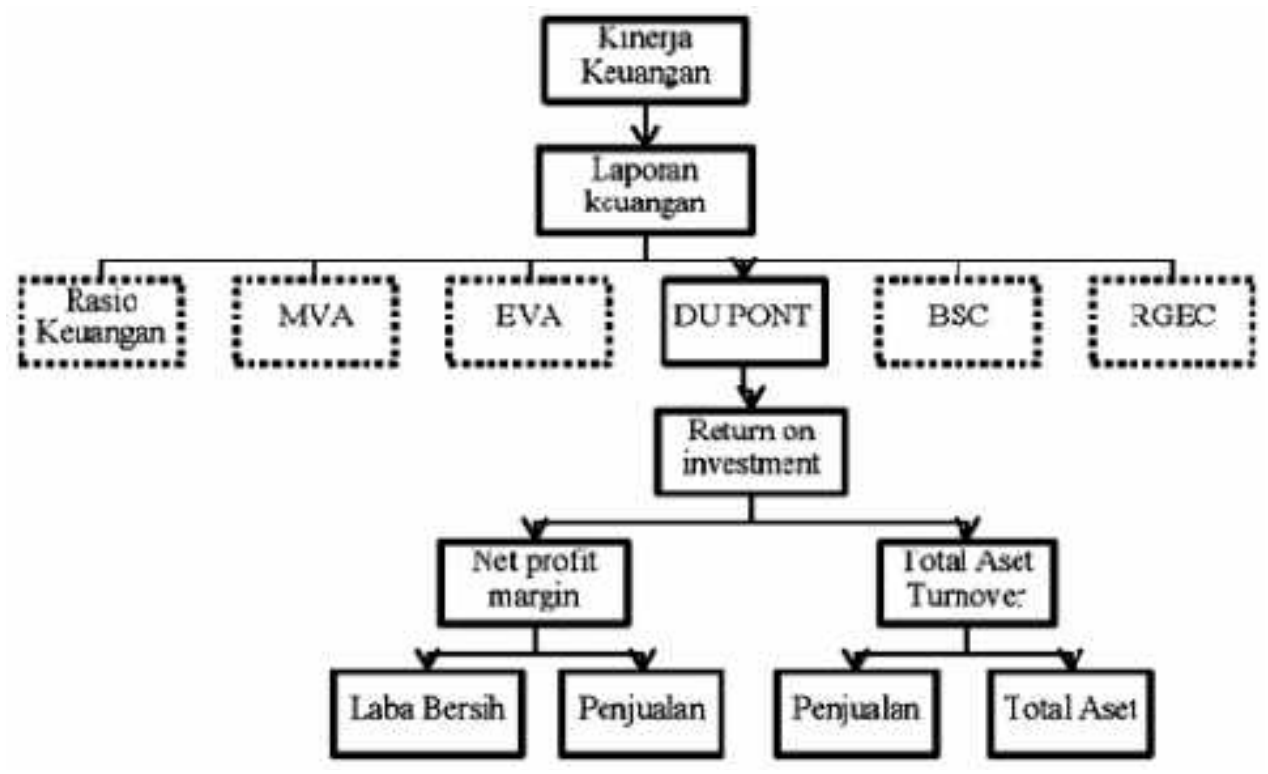

Sumber : diolah, 2015

Keterangan :

---- = Tidak diteliti dalam penelitian

— = Diteliti dalam penelitian

\section{METODE PENELITIAN}

\section{Objek Penelitian}

Objek pada penelitian ini adalah kinerja keuangan.

\section{Metode Penelitian}

Metode yang digunakan dalam penelitian adalah komparatif dengan pendekatan kuantitatif. Penelitian ini membandingkan kinerja keuangan PT Kalbe Farma Tbk dan PT Kimia Farma (Persero) Tbk tahun 2012 - 2014.

\section{Populasi dan Sampel}

Perusahaan farmasi yang telah melakukan Initial Public Offering sampai tahun 2014 sebanyak 10 perusahaan. Untuk menentukan ukuran sampel dalam penelitian ini maka digunakan tehnik non-probability sampling dengan jenisnya purposive sampling. Adapun yang menjadi pertimbangan dalam penentuan ukuran sampel ini adalah :

1. Perusahaan farmasi yang telah go public sampai tahun 2014.

2. Perusahaan tersebut merupakan perusahaan farmasi swasta murni atau farmasi BUMN.
3. Perusahaan tersebut pernah menjadi market leader.

Berdasarkan asumsi tersebut di atas maka perusahaan yang memenuhi ketentuan tersebut di atas adalah :

1. PT. Kalbe Farma Tbk,

2. PT. Kimia Farma (Persero) Tbk.

Adapun alasan diambilnya rentang waktu penelitian antara tahun 2012 sampai dengan 2014 adalah:

1. PT Kalbe Farma Tbk dan PT Kimia Farma (Persero) Tbk merupakan perusahaan farmasi yang menjadi market leader di tahun 2013 dalam kategori perusahaan farmasi swasta murni dan perusahaan farmasi BUMN,

2. Untuk mengetahui kondisi kinerja suatu perusahaan maka diperlukan tahun pembanding. Untuk itu perlu adanya cut off tahun pembanding yang digunakan, yaitu satu tahun sebelum dan satu tahun sesudah perusahaan tersebut menjadi market leader.

3. Untuk melakukan analisis keuangan, umumnya data yang digunakan minimal 3 tahun laporan keuangan perusahaan yang bersangkutan. 


\section{Operasionalisasi Variabel}

Penelitian ini membahas tentang analisis perbandingan kinerja keuangan menggunakan analisis Du Pont System. Berdasarkan judul tersebut maka terdapat satu jenis variabel yang digunakan yaitu variabel independen (X).

Adapun yang menjadi variabel independen adalah kinerja keuangan (X), yang diwakili oleh 2 sub variabel yaitu kinerja keuangan PT Kalbe Farma Tbk (X1), dan kinerja keuangan PT Kimia Farma (Persero) Tbk (X2). Untuk mengukur Kinerja keuangan dengan menggunakan Du Pont System digunakan rasio keuangan, yaitu ROI. Dan yang dijadikan sebagai indikator variabelnya adalah Total Asset Turnover dan Net Profit Margin.

\section{Teknik Pengumpulan Data}

Pengumpulan data pada penelitian ini dilakukan melalui studi kepustakaan yaitu pengumpulan informasi dengan melakukan studi telaah atas buku - buku maupun literatur, catatan serta laporan - laporan yang terkait dengan penelitian yang dilakukan

Sumber data yang digunakan dalam penelitian ini yaitu berupa data skunder berupa laporan keuangan PT Kalbe Farma Tbk dan PT Kimia Farma (Persero) Tbk yang di publikasikan oleh Bursa Efek Indonesia pada www.idx.co.id.

\section{Teknik Analisa Data}

Cara menganalisis data penulis menggunakan pendekatan kuantitatif yaitu dengan melakukan perhitungan yang relevan terhadap masalah yang diteliti. Adapun teknik analisis yang digunakan adalah $\mathrm{Du}$ Pont System dengan langkah-langkah sebagai berikut (Subramanyam dan Halsey, 2004):

1. Menghitung total aset

2. Menghitung penjualan

3. Menghitung Total Assets Turnover

4. Menghitung total biaya

5. Menghitung laba bersih

6. Menghitung Net profit margin

7. Menghitung Return on investment dengan metode Du Pont System

8. Melakukan penilaian rasio berdasarkan nilai-nilai rasio yang telah dihitung pada langkah sebelumnya

9. Melakukan penilaian kinerja keuangan dengan membandingkan antar perusahaan

10. Melakukan penilaian kinerja keuangan dengan cara membandingkannya dengan rata - rata industri perusahaan

11. Penarikan kesimpulan

\section{HASIL DAN PEMBAHASAN}

\section{Kinerja Keuangan PT Kalbe Farma Tbk tahun 2012 - 2014}

Kinerja keuangan merupakan ukuran prestasi perusahaan dimana keuntungan menjadi salah satu alat yang digunakan manajer untuk mengetahui kinerja keuangan perusahaan tersebut. Analisis kinerja keuangan pada penelitian ini dilakukan dengan menggunakan analisis Du Pont System untuk menghitung hasil pengembalian investasi atau return on investment dengan komponen- komponen yang diperlukan yaitu total assets turnover dan net profit margin. Total assets turnover merupakan perputaran total asset dalam menghasilkan penjualan. Net profit margin merupakan margin laba yang dihasilkan untuk setiap penjualan.

Tabel 2 Total Assets Turnover PT Kalbe Farma Tbk tahun 2012 - 2014 (Penjualan dan total aset dalam jutaan rupiah)

\begin{tabular}{|c|c|c|c|}
\hline Tahun & $\mathbf{2 0 1 2}$ & $\mathbf{2 0 1 3}$ & $\mathbf{2 0 1 4}$ \\
\hline Penjualan & 13.636 .405 & 16.002 .131 & 17.368 .532 \\
\hline Total aset & 9.417 .956 & 11.315 .060 & 12.425 .031 \\
\hline Total asset turnover & $1,45 \mathrm{Kali}$ & $1,41 \mathrm{Kali}$ & $1,40 \mathrm{kali}$ \\
\hline
\end{tabular}

Sumber: Laporan Keuangan PT Kalbe Farma Tbk yang diolah penulis 
Berdasarkan tabel diatas dapat diketahui bahwa total asset turnover PT Kalbe Farma Tbk terus mengalami penurunan. Selama tahun 2012 - 2014 total asset turnover perusahaan paling tinggi pada tahun 2012 sebesar 1,45 kali. Total assets turnover PT Kalbe Farma Tbk Tahun 2012 sebesar 1,45 kali, artinya perusahaan mampu menghasilkan penjualan sebesar 1,45 kali dari total asset yang dimilikinya. Semakin sering perputaran aset terjadi maka semakin baik perusahaan dalam menciptakan penjualan dengan memanfaatkan aset yang dimiliki. Jadi kondisi total assets turnover PT Kalbe Farma Tbk tahun 2012 2014 terus mengalami penurunan yang disebabkan oleh peningkatan jumlah total aktiva yang lebih besar dibandingkan dengan peningkatan penjualan.

Tabel 3 Net Profit Margin PT Kalbe Farma Tbk tahun 2012 - 2014 (dalam jutaan rupiah)

\begin{tabular}{|c|c|c|c|}
\hline Tahun & $\mathbf{2 0 1 2}$ & $\mathbf{2 0 1 3}$ & $\mathbf{2 0 1 4}$ \\
\hline Laba Bersih & 1.775 .098 & 1.970 .452 & 2.121 .090 \\
\hline Penjualan & 13.636 .405 & 16.002 .131 & 17.368 .532 \\
\hline Net Profit Margin & $13,01 \%$ & $12,31 \%$ & $12,21 \%$ \\
\hline
\end{tabular}

Sumber : Laporan laba rugi PT Kalbe Farma Tbk yang diolah penulis

Berdasarkan tabel diatas dapat diketahui bahwa net profit margin PT Kalbe Farma Tbk terus mengalami penurunan. Selama tahun 2012 - 2014 net profit margin perusahaan paling tinggi pada tahun 2012 sebesar 13,01\%. Jadi kondisi net profit margin PT Kalbe Farma Tbk tahun 2012 - 2014 terus mengalami penurunan yang disebabkan oleh peningkatan jumlah penjualan yang lebih tinggi dibandingkan dengan peningkatan laba bersih perusahaan. Peningkatan beban perusahaan lebih besar dibandingkan dengan peningkatan penjualannya.

Tabel 4 Return On Investment PT Kalbe Farma Tbk tahun 2012 - 2014

\begin{tabular}{|c|c|c|c|}
\hline Tahun & $\mathbf{2 0 1 2}$ & $\mathbf{2 0 1 3}$ & $\mathbf{2 0 1 4}$ \\
\hline Total Assets Turnover & $1,45 \mathrm{Kali}$ & $1,41 \mathrm{Kali}$ & $1,40 \mathrm{kali}$ \\
\hline Net Profit Margin & $13,01 \%$ & $12,31 \%$ & $12,21 \%$ \\
\hline Return On Investment & $18,86 \%$ & $17,35 \%$ & $17,09 \%$ \\
\hline
\end{tabular}

Sumber : Laporan keuangan PT Kalbe Farma Tbk yang diolah penulis

Berdasarkan tabel diatas dapat diketahui bahwa return on investment PT Kalbe Farma Tbk terus mengalami penurunan. Selama tahun 2012 - 2014 return on investment perusahaan paling tinggi pada tahun 2012 sebesar 18,86\% artinya pengembalian yang diperoleh sebesar $18,86 \%$ dari total asset yang dimiliki perusahaan. Jadi kondisi Return on investment PT Kalbe Farma Tbk tahun 2012 - 2014 terus mengalami penurunan yang disebabkan oleh penurunan pada total assets turnover karena peningkatan asset perusahaan lebih tinggi dibandingkan dengan penjualan dan penurunan pada net profit margin karena peningkatan laba bersih lebih rendah dari pada penjualan. Peningkatan laba bersih rendah karena menurunnya pendapatan yang diterima oleh perusahaan dan peningkatan total biaya yang lebih tinggi dari pada penjualan.

\section{Kinerja Keuangan PT Kimia Farma Tbk tahun 2012 - 2014}

Kinerja keuangan merupakan ukuran prestasi perusahaan dimana keuntungan menjadi salah satu alat yang digunakan manajer 
untuk mengetahui kinerja keuangan perusahaan tersebut. Analisis kinerja keuangan pada penelitian ini dilakukan dengan menggunakan analisis Du Pont System untuk menghitung hasil pengembalian investasi atau return on investment dengan komponen - komponen yang diperlukan yaitu total assets turnover dan net profit margin.

Tabel 5 Total Assets Turnover PT Kimia Farma Tbk tahun 2012 - 2014 (Penjualan dan total aset dalam jutaan rupiah)

\begin{tabular}{|c|c|c|c|}
\hline Tahun & 2012 & 2013 & 2014 \\
\hline Penjualan & 3.734 .241 & 4.348 .073 & 4.521 .024 \\
\hline Total Aset & 2.076 .347 & 2.471 .938 & 2.968 .183 \\
\hline Total assets turnover & $1,80 \mathrm{kali}$ & $1,76 \mathrm{kali}$ & $1,52 \mathrm{kali}$ \\
\hline
\end{tabular}

Sumber : Laporan Keuangan PT Kimia Farma Tbk yang diolah penulis

Tabel diatas dapat menunjukan bahwa total asset turnover PT Kimia Farma Tbk terus mengalami penurunan. Selama tahun 2012 2014 total asset turnover perusahaan paling tinggi pada tahun 2012 sebesar 1,80 kali. Total assets turnover PT Kimia Farma Tbk Tahun 2012 sebesar 1,8 kali, artinya perusahaan mampu menghasilkan penjualan sebesar 1,8 kali dari total asset yang dimilikinya. Semakin sering perputaran asset maka semakin baik pula perusahaan dalam menciptakan penjualan dengan memanfaatkan asset yang dimiliki. Jadi kondisi total assets turnover PT Kimia Farma Tbk tahun 2012 - 2014 terus mengalami penurunan yang disebabkan oleh peningkatan jumlah total aktiva yang lebih besar dibandingkan dengan peningkatan penjualan.

Tabel 6 Net Profit Margin PT Kimia Farma Tbk tahun 2012 - 2014 (laba bersih dan penjualan dalam jutaan rupiah)

\begin{tabular}{|c|c|c|c|}
\hline Tahun & 2012 & 2013 & 2014 \\
\hline Laba Bersih & 205.763 & 215.642 & 236.531 \\
\hline Penjualan & 3.734 .241 & 4.348 .073 & 4.521 .024 \\
\hline Net Profit Margin & $5,5 \%$ & $4,96 \%$ & $5,2 \%$ \\
\hline
\end{tabular}

Sumber: Laporan laba rugi PT Kimia Farma Tbk yang diolah penulis

Tabel diatas dapat menunjukan bahwa net profit margin PT Kimia Farma Tbk mengalami fluktuasi. Net profit margin perusahaan tahun 2012 sebesar 5,5\% kemudian pada tahun 2013 turun menjadi 4,96\% lalu meningkat lagi pada tahun 2014 menjadi sebesar 5,2\% Selama tahun paling tinggi pada tahun 2012 sebesar 5,5\%. Jadi kondisi net profit margin PT Kimia Farma Tbk tahun 2012 - 2014 mengalami fluktuasi yang disebabkan oleh perubahan peningkatan jumlah penjualan dan perubahan peningkatan laba bersih perusahaan.

Tabel 7 Return On Investment dengan Analisis Du Pont System PT Kimia Farma Tbk tahun 2012 - 2014

\begin{tabular}{|c|c|c|c|}
\hline Tahun & $\mathbf{2 0 1 2}$ & $\mathbf{2 0 1 3}$ & $\mathbf{2 0 1 4}$ \\
\hline Total Assets Turnover & $1,80 \mathrm{kali}$ & $1,76 \mathrm{kali}$ & $1,52 \mathrm{kali}$ \\
\hline Net Profit Margin & $5,5 \%$ & $4,96 \%$ & $5,2 \%$ \\
\hline Return On Investment & $9,9 \%$ & $8,73 \%$ & $7,9 \%$ \\
\hline
\end{tabular}

Sumber: Laporan keuangan PT Kimia Farma Tbk yang diolah penulis

Pada tabel diatas dapat menunjukan bahwa return on investment PT Kimia Farma Tbk terus mengalami penurunan. Selama tahun 2012 2014 return on investment perusahaan paling tinggi pada tahun 2012 sebesar 9,9\%. Return On Investment pada PT Kimia Farma Tbk tahun 2012 sebesar 9,9\% artinya pengembalian yang diperoleh sebesar 9,9\% dari total asset yang 
dimiliki perusahaan. Return on investment ini diperoleh sebagai hasil perkalian antara total asset turnover sebanyak 1,8 kali dan net profit margin sebesar 5,5\%. Jadi kondisi Return on investment PT Kalbe Farma Tbk tahun 2012 2014 terus mengalami penurunan yang disebabkan oleh penurunan pada total assets turnover karena peningkatan asset perusahaan lebih tinggi dibandingkan dengan penjualan dan fluktuasi net profit margin karena perubahan peningkatan jumlah penjualan dan perubahan peningkatan laba bersih perusahaan.

Analisis Perbandingan Kinerja Keuangan antara PT Kalbe Farma Tbk dan PT Kimia Farma Tbk tahun 2012 - 2014 dengan Menggunakan Du Pont System

Tabel 8 Perbandingan Total Assets Turnover PT Kalbe Farma Tbk dan PT Kimia Farma Tbk tahun $2012-2014$

\begin{tabular}{|c|c|c|c|}
\hline Tahun & $\mathbf{2 0 1 2}$ & $\mathbf{2 0 1 3}$ & $\mathbf{2 0 1 4}$ \\
\hline Kalbe Farma Tbk & 1,45 Kali & 1,41 Kali & 1,40 kali \\
\hline Kimia Farma Tbk & 1,80 kali & 1,76 kali & 1,52 kali \\
\hline
\end{tabular}

Sumber: Laporan Keuangan dari dua perusahaan yang telah diolah

Tabel diatas menunjukan bahwa total assets turnover PT Kalbe Farma Tbk dan PT Kimia Farma Tbk tahun 2012 - 2014 mengalami penurunan terus menerus. Keseluruhan total assets turnover PT Kalbe Farma Tbk lebih rendah dibandingkan dengan total assets turnover PT Kimia Farma Tbk. Hal tersebut menunjukan bahwa PT Kimia Farma Tbk memiliki kinerja keuangan yang lebih baik dari pada PT Kalbe Farma Tbk dalam memanfaatkan asset yang dimilikinya. Jadi jika dibandingkan dari total asset turnover tahun 2012 - 2014 PT Kimia Farma Tbk memiliki kinerja keuangan yang lebih baik dari pada PT Kalbe Farma Tbk dalam memanfaatkan asset yang dimilikinya.

Tabel 9 Perbandingan Net Profit Margin PT Kalbe Farma Tbk dan PT Kimia Farma Tbk tahun 2012-2014

\begin{tabular}{|c|c|c|c|}
\hline Tahun & $\mathbf{2 0 1 2}$ & $\mathbf{2 0 1 3}$ & $\mathbf{2 0 1 4}$ \\
\hline Kalbe Farma & $13,01 \%$ & $12,31 \%$ & $12,21 \%$ \\
\hline Kimia Farma & $5,5 \%$ & $4,96 \%$ & $5,2 \%$ \\
\hline
\end{tabular}

Sumber: Laporan Keuangan dari dua perusahaan yang telah diolah

Tabel diatas dapat menunjukan bahwa net profit margin PT Kalbe Farma Tbk tahun 2012 - 2014 mengalami penurunan terus menerus sedangkan net profit margin PT Kalbe Farma Tbk tahun 2012 - 2014 mengalami fluktuatif. Keseluruhan net profit margin PT Kalbe Farma Tbk lebih tinggi dibandingkan dengan total assets turnover PT Kimia Farma Tbk. Hal tersebut menunjukan bahwa PT Kalbe Farma
Tbk memiliki kinerja keuangan yang lebih baik dari pada PT Kimia Farma Tbk dalam menghasilkan laba dari setiap penjualannya. Jadi jika dibandingkan dari komponen net profit margin tahun 2012 - 2014, kemampuan PT Kalbe Farma Tbk dalam memperoleh laba bersih dari penjualannya lebih baik dari pada PT Kimia Farma Tbk. 
Tabel 10 Perbandingan Return On Investment dengan analisis Du Pont System PT Kalbe Farma Tbk dan PT Kimia Farma Tbk tahun 2012 - 2014

\begin{tabular}{|c|c|c|c|}
\hline Tahun & 2012 & 2013 & 2014 \\
\hline Kalbe Farma Tbk & $18,86 \%$ & $17,35 \%$ & $17,09 \%$ \\
\hline Kimia Farma Tbk & $9,9 \%$ & $8,73 \%$ & $7,9 \%$ \\
\hline Rata Rata Industri & $12,64 \%$ & $11,87 \%$ & $10,42 \%$ \\
\hline
\end{tabular}

Sumber : Laporan Keuangan perusahaan farmasi yang telah diolah

Tabel di atas menunjukan bahwa return on investment PT Kalbe Farma Tbk dan PT Kimia Farma Tbk tahun 2012 - 2014 mengalami penurunan terus menerus, begitu pula dengan return on investment rata - rata industri perusahaan farmasi. Keseluruhan return on investment dari tahun 2012 - 2014 PT Kalbe Farma Tbk lebih tinggi dibandingkan dengan return on investment PT Kimia Farma Tbk. Hal tersebut menunjukan bahwa PT Kalbe Farma Tbk memiliki kinerja keuangan yang lebih baik dari pada PT Kimia Farma Tbk dalam perolehan pengembalian hasil investasi perusahaan. Jadi jika dibandingkan dari return on investment tahun 2012 - 2014, PT Kalbe Farma Tbk memiliki kinerja keuangan yang lebih baik dari pada PT Kimia Farma Tbk dalam pengembalian hasil investasi perusahaan berupa aset perusahaan. Return on investment PT Kalbe Farma Tbk berada di atas rata - rata industri sedangkan return on investment PT Kimia Farma Tbk berada di bawah rata - rata industri, hal tersebut juga menunjukan bahwa kinerja keuangan PT Kalbe Farma Tbk lebih baik dari pada PT Kimia Farma Tbk.

\section{SIMPULAN}

Berdasarkan hasil penelitian dapat disimpulkan bahwa

1. Kinerja keuangan PT Kalbe Farma Tbk menggunakan analisis Du Pont System tahun 2012-2014 terus mengalami penurunan yang dapat diketahui dari menurunnya return on investment.

2. Kinerja keuangan PT Kimia Farma Tbk menggunakan analisis Du Pont System tahun 2012-2014 mengalami penurunan yang dapat diketahui dari menurunnya retun on investment.

3. Kinerja keuangan PT Kalbe Farma Tbk lebih baik dibandingkan dengan kinerja keuangan PT Kimia Farma Tbk tahun 2012 - 2014. Return on investment PT Kalbe Farma Tbk selalu lebih tinggi dibandingkan dengan PT kimia Farma Tbk. Kinerja keuangan PT Kalbe Farma Tbk dapat dikatakan baik karena memiliki return on investment di atas rata - rata industri sedangkan kinerja keuangan PT Kimia Farma Tbk dapat dikatakan tidak baik karena memiliki return on investment di bawah rata rata industri.

\section{DAFTAR PUSTAKA}

Dwi Lestari, Wuryaningsih \& Dziqron, Muhammad. 2014. Penerapan Du Pont System Untuk Mengukur Kinerja Perusahaan (Studi pada Perusahaan Semen yang Terdaftar di BEI tahun 2007-2011). Jurnal Fakultas Ekonomi dan Bisnis Universitas Muhammadiyah Surakarta.

Gitman, Lawrence J. 2009. Principles of Managerial Finance. twelefth edition. Boston. Pearson International

Harahap, Sofyan Syafri. 2015. Analisis Kritis Atas Laporan keuangan. Jakarta. PT Raja Grafindo Persada.

Jumingan. 2011. Analisis Laporan Keuangan. Jakarta. Penerbit Bumi Aksara.

Munawir. 2014. Analisa Laporan Keuangan. Yogyakarta. Liberty.

Ross, A. Stephen et al. 2002. Fundamentals of Corporate Finance. fifth edition. United State of America. Mc Graw-Hill Higher Education

Subramanyam, Wild John J dan Robert F. Halsey. 2004. Financial Statement Analysis. The McGraw-Hill Companies Inc., diterjemahkan oleh Yanivi S. Bachtiar dan S. Nurwahyu Harahap. 2005. Analisis Laporan Keuangan. Jakarta. Salemba 
Empat

Suwita, Leli. 2013. Analisis Du Pont System

Dalam Mengukur Kinerja Keuangan

Perusahaan.Jurnal FE UMB Vol 1 No.34.

Warsono. 2003. Manajemen Keuangan

Perusahaan. Malang. Bayumedia.

Van Horne, C James dan John M. Machowicz,

JR. 2008.Fundamentals of financial

management. thirhteenth edition. Prentice

Hall Imprint. England

\section{Sumber lain:}

www.idx.co.id (diakses 7 Oktober 2015)

www.jpnn.com (diakses 10 Oktober 2015)

http://indonesia-pharmacommunity.blogspot.co.

id/ (diakses 10 Oktober 2015) 